\title{
Hubungan Pendapatan, Tingkat Asupan Energi dan Karbohidrat dengan Status Gizi Balita Usia 2-5 Tahun di Daerah Kantong Kemiskinan
}

\section{The Correlation of Income, Level of Energy and Carbohydrate Intake with Nutritional Status of Toddlers Aged 2-5 Years in Poor District}

\author{
Lutfiyatul Afifah*1
}

\begin{abstract}
ABSTRAK
Latar Belakang: Status gizi balita penting diperhatikan karena balita rentan mengalami masalah gizi. Masalah gizi pada balita masih banyak terjadi. Status gizi balita dapat dipengaruhi oleh beberapa faktor diantaranya yaitu tingkat asupan zat gizi termasuk energi dan karbohidrat serta pendapatan keluarga. Rendahnya asupan zat gizi dapat mengakibatkan masalah gizi balita. Pendapatan keluarga berkaitan dengan kemampuan memenuhi asupan pangan keluarga.
\end{abstract}

Tujuan: Untuk menganalisis hubungan antara pendapatan, tingkat asupan energi, dan karbohidrat dengan status gizi balita usia 2-5 tahun di Kecamatan Lenteng Kabupaten Sumenep.

Metode: Desain penelitian yang digunakan adalah cross sectional. Jumlah sampel 70 orang tua balita berusia 2 hingga 5 tahun. Pengukuran berat badan dan tinggi badan balita untuk menilai status gizi. Wawancara kepada orang tua untuk mengetahui karakteristik balita dan pendapatan keluarga serta food recall $2 \times 24$ hours untuk mengetahui tingkat asupan balita. Data dianalisis menggunakan uji korelasi spearman dengan $\alpha=0,05$.

Hasil: Sebanyak $57,1 \%$ responden berpendapatan rendah. Sebanyak $65,7 \%$ tingkat asupan energi adalah inadequate dan $95,7 \%$ karbohidrat adalah kurang. Prevalensi status gizi normal $84,3 \%$, kurus $11,4 \%$ dan sangat kurus $2,9 \%$. Hasil analisis menyebutkan ada hubungan antara tingkat asupan energi $(p=0,040)$ dan tingkat asupan karbohidrat $(p=0,045)$ dengan status gizi balita. Sedangkan pendapatan tidak berhubungan dengan status gizi balita $(p=0,649)$.

Kesimpulan: Pendapatan keluarga berhubungan dengan status gizi balita. Tingkat asupan zat gizi yang kurang dapat meningkatkan risiko masalah gizi balita. Maka perlu dilakukan peningkatan asupan zat gizi untuk memperoleh status gizi yang baik atau normal.

Kata kunci: pendapatan, status gizi balita, tingkat asupan energi, tingkat asupan karbohidrat

ABSTRACT

Background: Nutritional status of toddlers is considered important since they are generally more susceptible to nutritional problem. Some factors that affect them is level of nutrient intake, which include level of energy intake, carbohydrate intake, and family income. Family income is associated with the ability to provide food, thus affecting the level of nutrient intake for the family.

Objectives: The objective of the study was to analyze the correlation between incomes, level of energy and carbohydrate intake with nutritional status of toddlers aged 2-5 years in Lenteng sub-District, Sumenep.

Methods: the design of this study was cross sectional. Sample size was 70 parents of toddlers aged 2-5 years in Lenteng sub-District, Sumenep. Weight and height of the toddlers were measured to determine the nutritional status of the toddlers. Interviews with parents were also conducted to determine the characteristic of the toddlers and the family income. Lastly, 2 $x 24$ hours food recall was used to examine the level of their nutrient intake. The data were analyzed by using Spearman correlation test with $\alpha=0.05$.

Results: The results showed that $57.1 \%$ toddlers were in low income category. $65.7 \%$ toddlers were in inadequate level of energy intake. 95.7\% were in inadequate level of carbohydrate intake. Prevalence of toddlers with normal nutritional status normal were $84.3 \%, 11.4 \%$ was malnourished, while $2.9 \%$ was severely malnourished. The result showed that level of energy intake and carbohydrate intake are related to nutritional status of toddlers $(p=0.040)$ and $(p=0.045)$. However, there was no correlation found between family incomes with toddlers' family income.

Conclusions: Family income was not found to be related to the nutritional status of toddlers. While the lower level of nutrient intake can potentially affect nutritional problem among toddlers. Thus, an adequate nutrient intake is required to help toddlers meet their balanced nutritional needs. 
Keywords: income, nutritional status, level of energy intake, level of carbohydrate intake

\author{
*Koresponden: \\ lutfiyatulafifah95@gmail.com \\ ${ }^{1}$ Departemen Gizi Kesehatan, Fakultas Kesehatan Masyarakat, Universitas Airlangga, Kampus C Mulyorejo 66115, \\ Surabaya, Jawa Timur, Indonesia
}

\section{PENDAHULUAN}

Pembangunan bangsa dapat didukung dengan memperbaiki kualitas sumber daya manusia, salah satunya adalah status gizi balita. Status gizi balita adalah faktor penting pada daur kehidupan karena pada kategori usia balita ini merupakan periode peningkatan perkembangan dan pertumbuhan yang pesat namun rentan dengan masalah gizi. ${ }^{1}$ Masalah gizi balita masih menjadi perhatian karena masih banyak kasus gizi kurang dan gizi buruk di beberapa daerah di Indonesia. Masalah gizi pada balita dapat menurunkan kecerdasan, produktifitas, dan kreatifitas sehingga berkaitan dengan penurunan kualitas SDM. ${ }^{2}$ Hasil Riskesdas tahun 2013 menyebutkan bahwa prevalensi gizi kurang dan buruk pada tingkat nasional sebesar $13,95 \%$ dan 5,7\%. Prevalensi ini mengalami penurunan di tahun 2018 yaitu status gizi kurang dan buruk pada tingkat nasional menjadi $13,8 \%$ dan 3,9\%. Penurunan prevalensi gizi buruk pada tahun 2018 cukup signifikan sedangkan penurunan prevalensi gizi kurang adalah rendah yaitu 1\%. Hasil Pemantauan Status Gizi (PSG) Nasional tahun 2017 menunjukkan prevalensi balita gizi buruk dan gizi kurang di Provinsi Jawa Timur sebesar 2,9\% dan 12,6\%. Sedangkan berdasarkan data dari Dinas Kesehatan Kabupaten Sumenep, di Kecamatan Lenteng diketahui prevalensi balita gizi buruk sebesar $0,12 \%$ dan balita gizi kurang 25,67\%. Prevalensi gizi kurang Kecamatan Lenteng lebih tinggi dibadingkan prevalensi gizi kurang di tingkat provinsi maupun nasional, sehingga perlu perhatian lebih pada balita di daerah ini.

Status gizi pada balita dapat dipengaruhi oleh asupan zat gizi balita. Asupan zat gizi makro berperan dalam penyediaan energi dan berhubungan dengan status gizi balita. ${ }^{3}$ Perubahan status gizi menjadi baik atau normal dapat dipengaruhi oleh tingkat asupan energi yang cukup. ${ }^{4}$ Selain itu, tingkat asupan dapat dipengaruhi oleh kondisi ekonomi. Kondisi ekonomi yang rendah atau miskin dapat menyebabkan kebutuhan zat gizi balita yang berasal dari asupan makanan tidak tercukupi. ${ }^{5}$ Pendapatan keluarga dapat menentukan tingkat asupan zat gizi berdasarkan daya beli terhadap pangan. Tingginya pendapatan memungkinkan keluarga untuk meningkatkan daya beli terhadap pangan. ${ }^{6}$ Menurut Badan Pusat Statistik (BPS) Kabupaten Sumenep, pada tahun 2017 Kabupaten Sumenep berada pada urutan ke 4 daerah dengan presentase penduduk miskin tertinggi dengan jumlah $19,62 \%$. Jumlah ini lebih tinggi jika dibandingkan dengan presentase penduduk miskin Jawa Timur yaitu $11,77 \%$.

Penelitian ini yang bertujuan untuk menganalisis hubungan pendapatan, tingkat asupan energi dan karbohidrat dengan status gizi balita berusia 2-5 tahun di Kecamatan Lenteng Kabupaten Sumenep. Daerah ini dipilih karena merupakan salah satu daerah kantong kemisikinan di Jawa Timur dan memiliki prevalensi balita gizi kurang yang lebih tinggi dari tingkat

provinsi dan nasional. Sehingga perlu untuk dilakukan penelitian kepada balita terkait status gizi.

\section{METODE}

Jenis penelitian yang digunakan adalah cross sectional. Teknik simple random sampling digunakan dalam pengambilan sampel dengan jumlah sampel 70 . Kriteria inklusi responden pada penelitian ini adalah balita yang sedang tidak mengalami sakit atau baru sembuh dari sakit dalam waktu $\geq 3$ hari dan berusia 2-5 tahun yang tinggal di Kecamatan Lenteng Kabupaten Sumenep.

Penelitian dilaksanakan pada bulan Agustus hingga September 2018. Variabel bebas yaitu pendapatan yang diperoleh keluarga, tingkat asupan balita terkait energi dan karbohidrat. Variabel status gizi balita usia 2-5 tahun sebagai variabel terikat. Pengambilan data dilakukan dengan mengukur berat badan balita menggunakan timbangan digital dan mengukur tinggi badan balita menggunakan microtoise untuk menentukan status gizi balita dengan mencari nilai $z$-score. Penilaian status gizi balita berdasarkan indikator $\mathrm{BB} / \mathrm{TB}$ terdiri dari 4 kategori yaitu sangat kurus (<-3 SD), kurus (-3 SD sampai <-2 SD), normal (-2 SD sampai 2 SD), dan gemuk $(>+2 \mathrm{SD})$. Instrumen penelitian ini adalah formulir biodata balita untuk memperoleh data mengenai karakteristik balita yaitu usia dan jenis kelamin balita. Formulir pendapatan untuk memperoleh data jumlah pendapatan keluarga dan dikategorikan menjadi rendah (<UMK Sumenep) dan tinggi (>UMK Sumenep). Pengkategorian ini berdasarkan nilai Upah Minimum Kabupaten (UMK) Sumenep yaitu Rp 1.645.146,48. Formulir $2 \times 24$ hours food recall untuk menilai tingkat asupan zat gizi balita yaitu energi dan karbohidrat. Tingkat asupan energi dikategorikan menjadi inadequate $(<77 \%$ AKG) dan adequate ( $>77 \%$ AKG) menurut Gibson (2005). Tingkat asupan karbohidrat dikategorikan menjadi kurang $(<45 \%$ energi), cukup $(45 \%-65 \%$ energi), dan lebih ( $>65 \%$ energi) berdasarkan Acceptable Macronutrient Distribution Range. Uji statistik menggunakan ui korelasi spearman dengan $\alpha=0,05$ untuk menganalisis hubungan antara pendapatan, tingkat asupan energi dan karbohidrat dengan status gizi balita.

Penelitian ini telah memperoleh izin dari Komisi Etik Fakultas Kesehatan Masyarakat Universitas Airlangga nomer 486-KEPK tanggal 18 Agustus 2018.

\section{HASIL DAN PEMBAHASAN}

Distribusi karakteristik responden terdapat pada tabel 1, Karakteristik balita meliputi usia yang dikelompokkan ke dalam 3 kategori dan 2 kategori jenis 
kelamin yaitu laki-laki dan perempuan. Responden penelitian didominasi oleh balita pada kelompok usia 3 $<4$ tahun sebanyak $48,6 \%$. Distribusi karakteristik jenis kelamin responden menunjukkan dominan jenis kelamin responden adalah laki-laki yaitu sebanyak $57,1 \%$ sedangkan lainnya adalah jenis kelamin perempuan. Pada kelompok usia $3-<4$ tahun, balita telah memiliki pilihan sendiri tentang makanan yang ingin dikonsumsi. ${ }^{7}$ Usia dapat menentukan kebutuhan kebutuhan zat gizi balita karena semakin bertambahnya usia balita maka kebutuhan gizinya semakin meningkat. ${ }^{8}$ Perbedaan kebutuhan zat gizi terutama pada dewasa antara jenis kelamin laki-laki dan perempuan berkaitan dengan jaringan penyusun tubuh dan jenis aktifitasnya. ${ }^{8}$ Berdasarkan hasil dari penelitian diketahui bahwa balita kurus lebih banyak terdapat pada responden dengan jenis kelamin perempuan dibandingkan laki-laki.

Tabel 1. Distribusi Karakteristik Balita di Kecamatan Lenteng Kabupaten SumenepTahun 2018

\begin{tabular}{lcc}
\hline \multirow{2}{*}{ Karakteristik } & \multicolumn{2}{c}{ Jumlah Responden } \\
\cline { 2 - 3 } & $\mathbf{n}$ & $\mathbf{\%}$ \\
\hline Usia Balita & 16 & 22,9 \\
$2-<3$ tahun & 34 & 48,6 \\
$3-<4$ tahun & 20 & 28,6 \\
$4-\leq 5$ tahun & $\mathbf{7 0}$ & $\mathbf{1 0 0 , 0}$ \\
\hline Total & & \\
\hline Jenis Kelamin Balita & 40 & 57,1 \\
$\quad$ Laki-laki & 30 & 42,9 \\
$\quad$ Perempuan & $\mathbf{7 0}$ & $\mathbf{1 0 0 , 0}$ \\
\hline Total & & \\
\hline
\end{tabular}

Tabel 2. Distribusi Status Gizi BB/TB Balita di Kecamatan Lenteng Kabupaten Sumenep Tahun 2018

\begin{tabular}{lrc} 
& \multicolumn{2}{c}{ Jumlah Responden } \\
\cline { 2 - 3 } Status Gizi Balita (BB/TB) & $\mathbf{n}$ & $\mathbf{\%}$ \\
\hline Sangat kurus & 2 & 2,9 \\
Kurus & 8 & 11,4 \\
Normal & 59 & 84,3 \\
Gemuk & 1 & 1,4 \\
\hline Total & $\mathbf{7 0}$ & $\mathbf{1 0 0 , 0}$ \\
\hline
\end{tabular}

Tabel 3.Distribusi Tingkat Asupan Energi dan Karbohidrat Balita di Kecamatan Lenteng Kabupaten Sumenep Tahun 2018

\begin{tabular}{lcc}
\hline \multirow{2}{*}{ Tingkat Asupan Zat Gizi } & \multicolumn{2}{c}{ Jumlah Responden } \\
\cline { 2 - 3 } & $\mathbf{n}$ & $\mathbf{\%}$ \\
\hline Energi & & \\
$\quad$ Inadequate & 46 & 65,7 \\
$\quad$ Adequate & 24 & 34,3 \\
\hline Total & $\mathbf{7 0}$ & $\mathbf{1 0 0 , 0}$ \\
\hline Karbohidrat & & \\
$\quad$ Kurang & 67 & 95,7 \\
Cukup & 3 & 4,3 \\
$\quad$ Lebih & 0 & 0,0 \\
\hline Total & $\mathbf{7 0}$ & $\mathbf{1 0 0 , 0}$ \\
\hline
\end{tabular}

Tabel 2 menampilkan distribusi status gizi responden berdasarkan indikator BB/TB. Sebanyak $84,3 \%$ responden balita memiliki status gizi normal. Balita dengan status gizi yang baik dapat memiliki status kesehatan dan pertumbuhan yang baik sesuai dengan usianya. Status gizi normal pada balita akan berpengaruh baik pada perkembangan dan pertumbuhan fisik serta kognitif, begitupula sebaliknya. ${ }^{9}$ Selain berpengaruh pada perkembangan dan pertumbuhan, masalah gizi juga dapat berakibat pada kecatatan hingga kejadian mortalitas. ${ }^{10}$ Penliaian status gizi berdasarkan indikator BB/TB dapat menggambarkan indikasi terhadap masalah gizi yang bersifat akut sebagai dampak dari kurangnya asupan. ${ }^{11}$ Asupan zat gizi dari makanan dan proses penyerapannya dalam tubuh dapat mempengaruhi status gizi. ${ }^{12}$ Kecukupan tingkat asupan zat gizi makro yang baik dapat meningkatkan status gizi balita. ${ }^{13}$ Pada tabel 3 diperoleh hasil bahwa sebagian besar tingkat asupan energi dan karbohidrat adalah kurang yaitu $65,7 \%$ dan $95,7 \%$. Ketidakseimbangan asupan energi dan karbohidrat serta zat gizi makro lainnya dengan kebutuhan yang terjadi terus menerus dapat mengakibatkan perubahan negatif berat badan yang merupakan salah satu indikator penilaian status gizi. ${ }^{3}$

Tabel 4 menunjukkan bahwa balita yang memiliki tingkat asupan energi inadequate sebagian besar berstatus gizi kurus $15,2 \%$. Sedangkan balita yang memiliki tingkat asupan energi adequate sebagian besar berstatus gizi normal dan gemuk ( $91,6 \%$ dan $4,2 \%$ ). Uji statistik menyatakan tingkat asupan energi balita dengan status gizi memiliki hubungan signifikan dengan hasil nilai $p=0,040$ dan berhubungan searah. Berdasarkan hasil penelitian yang telah dilakukan, dapat diketahui bahwa tingkat asupan energi yang cukup akan meningkatkan status gizi balita menjadi baik atau normal. Hasil ini didukung oleh penelitian sebelumnya yang memberikan kesimpulan bahwa tingkat kecukupan energi dengan status gizi memiliki hubungan signifikan. ${ }^{14}$ Penelitian lain menyebutkan kurangnya tingkat asupan energi dapat meningkatkan risiko 2,9 kali terjadinya status gizi kurang jika dibandingkan dengan balita yang tingkatan asupan energinya cukup. ${ }^{10}$ Energi yang diperoleh dari makanan dapat berasal dari zat gizi makro seperti karbohidrat, lemak, dan protein untuk metabolisme tubuh dan aktifitas fisik. $^{3}$

Tingkat asupan karbohidrat kurang mayoritas terdapat pada balita berstatus gizi kurus sebesar $11,9 \%$ sedangkan tingkat asupan karbohidrat cukup paling banyak terdapat pada balita dengan status gizi gemuk yaitu sebesar $33,35 \%$. Uji statistik pada variabel karbohidrat dan status gizi menyimpulkan bahwa keduanya adalah berhubungan secara signifikan dengan nilai $p=0,045$. Penelitian serupa mengatakan bahwa asupan karbohidrat dengan status gizi balita berdasarkan BB/TB adalah berhubungan signifikan. ${ }^{15}$ Penelitian lain yang dilakukan di Kabupaten Tolitoli tahun 2017 memberikan hasil yang sama, yaitu asupan karbohidrat dengan status gizi balita memiliki hubungan yang signifikan. ${ }^{16}$ Sumber energi tubuh utamanya berasal dari karbohidrat, asupan karbohidrat cukup berkaitan dengan energi yang cukup. ${ }^{13}$ Proses glikolisis menghasilkan energi yang berasal dari makanan berkaitan dengan kandungan glukosanya. ${ }^{17}$ Asupan karbohidrat yang berlebih kemudian dapat disimpan dalam bentuk glikogen dan lemak sehingga menyebabkan kelebihan berat badan atau gemuk. ${ }^{18}$ 
Tabel 4. Hubungan Tingkat Asupan Energi dan Karbohidrat dengan Status Gizi BB/TB Balita di Kecamatan Lenteng Kabupaten Sumenep Tahun 2018

\begin{tabular}{|c|c|c|c|c|c|c|c|c|c|c|c|}
\hline \multirow{3}{*}{ Tingkat Asupan Zat Gizi } & \multicolumn{8}{|c|}{ Status gizi BB/TB } & \multicolumn{2}{|c|}{ Total } & \multirow{3}{*}{ Nilai $p$} \\
\hline & \multicolumn{2}{|c|}{$\begin{array}{l}\text { Sangat } \\
\text { Kurus }\end{array}$} & \multicolumn{2}{|c|}{ Kurus } & \multicolumn{2}{|c|}{ Normal } & \multicolumn{2}{|c|}{ Gemuk } & \multirow[t]{2}{*}{$\mathbf{n}$} & \multirow[t]{2}{*}{$\%$} & \\
\hline & $\mathbf{n}$ & $\%$ & $\mathbf{n}$ & $\%$ & $\mathbf{n}$ & $\%$ & $\mathbf{n}$ & $\%$ & & & \\
\hline \multicolumn{12}{|l|}{ Tingkat Asupan Energi } \\
\hline Inadequate & 2 & 4,3 & 7 & 15,2 & 37 & 80,5 & 0 & 0 & 46 & 100 & 0,040 \\
\hline Adequate & 0 & 0 & 1 & 4,2 & 22 & 91,6 & 1 & 4,2 & 24 & 100 & \\
\hline \multicolumn{12}{|l|}{ Tingkat Asupan Karbohidrat } \\
\hline Kurang & 2 & 3,0 & 8 & 11,9 & 57 & 85,1 & 0 & 0 & 67 & 100 & \multirow{3}{*}{0,045} \\
\hline Cukup & 0 & 0 & 0 & 0 & 2 & 66,7 & 1 & 33,3 & 3 & 100 & \\
\hline Lebih & 0 & 0 & 0 & 0 & 0 & 0 & 0 & 0 & 0 & 100 & \\
\hline
\end{tabular}

Tabel 5. Distribusi Pendapatan Keluarga Balita di Kecamatan Lenteng Kabupaten Sumenep Tahun 2018

\begin{tabular}{lcc}
\hline \multirow{2}{*}{ Pendapatan Keluarga } & \multicolumn{3}{c}{ Jumlah Responden } \\
\cline { 2 - 3 } & 40 & \% \\
\hline Rendah $<1.645 .146,48$ & 30 & 57,1 \\
Tinggi $\geq 1.645 .146,48$ & $\mathbf{7 0}$ & 42,9 \\
\hline Total & & $\mathbf{1 0 0 , 0}$ \\
\hline
\end{tabular}

Tabel 6. Hubungan Pendapatan Keluarga dengan Status Gizi BB/TB Balita di Kecamatan Lenteng Kabupaten Sumenep Tahun 2018

\begin{tabular}{|c|c|c|c|c|c|c|c|c|c|c|c|}
\hline \multirow{3}{*}{ Pendapatan Keluarga } & \multicolumn{8}{|c|}{ Status gizi } & \multicolumn{2}{|c|}{ Total } & \multirow{3}{*}{ Nilai $p$} \\
\hline & \multicolumn{2}{|c|}{$\begin{array}{c}\begin{array}{c}\text { Sangat } \\
\text { kurus }\end{array} \\
\end{array}$} & \multicolumn{2}{|c|}{ Kurus } & \multicolumn{2}{|c|}{ Normal } & \multicolumn{2}{|c|}{ Gemuk } & \multirow[t]{2}{*}{$\mathbf{n}$} & \multirow[t]{2}{*}{$\%$} & \\
\hline & $\mathbf{n}$ & $\%$ & $n$ & $\%$ & $\mathbf{n}$ & $\%$ & $\mathbf{n}$ & $\%$ & & & \\
\hline Rendah $(<1.645 .146,48)$ & 0 & 0,0 & 7 & 17,5 & 32 & 80 & 1 & 2,5 & 40 & 100 & 0640 \\
\hline Tinggi $(>1.645 .146,48)$ & 2 & 6,7 & 1 & 3,3 & 27 & 90 & 0 & 0,0 & 30 & 100 & \\
\hline
\end{tabular}

Tabel 5 menyajikan data distribusi jumlah responden menurut pendapatan keluarga. Sebagian besar pendapatan keluarga responden adalah rendah dengan jumlah $57,1 \%$. Pendapatan keluarga dapat didefiniskan jumlah uang yang didapatkan oleh seluruh anggota keluarga dari hasil kerja selama periode tertentu. Pendapatan dapat berupa gaji, upah, tunjangan, dan pensiun. ${ }^{19}$ Keluarga yang memiliki pendapatan rendah berisiko menurunkan status gizi balita jika dibandingkan dengan keluarga berpendapatan tinggi. $^{20}$ Konsumsi harian keluarga dapat dipengaruhi oleh tingkat pendapatan keluarga. Keluarga berpendapatan rendah cenderung membeli makanan dengan lebih memperhatikan nilai ekonomi dibandingkan nilai gizi sehingga asupan yang berasal dari makanan tidak dapat memenuhi kecukupan zat gizi. ${ }^{4}$ Pendapatan dapat menentukan makanan yang dikonsumsi oleh keluarga termasuk balita berdasarkan jumlah dan jenisnya. ${ }^{21}$

Tabel 6 menunjukkan balita dengan pendapatan keluarga rendah (<UMK Sumenep) memiliki prevalensi gemuk yang tinggi yaitu sebesar $2,5 \%$, Sedangkan pada keluraga berpendapatan tinggi sebagian besar memiliki balita berstatus gizi sangat kurus $(6,7 \%)$. Uji statistik memberikan hasil nilai $p=0,649$ yang dapat diartikan bahwa pendapatan dengan status gizi balita berdasarkan BB/TB tidak memiliki hubungan. Keluarga dengan pendapatan yang cukup atau tinggi akan memungkinkan untuk membeli pangan yang lebih baik secara kualitas maupun kuantitas sehingga dapat memenuhi kecukupan zat gizinya. ${ }^{8}$ Namun berdasarkan hasil temuan selama penelitian, diketahui bahwa jenis makanan yang dikonsumsi oleh balita pada keluarga dengan pendapatan rendah maupun tinggi tidak banyak berbeda. Jenis makanan yang sering dikonsumsi yaitu nasi putih, nasi jagung, daging ayam, ikan tongkol, telur, tahu, tempe, bakso, sayur bayam, sayur daun kelor, dan sayur sop. Berdasarkan hasil recall $2 \times 24$ jam diketahui bahwa balita dengan keluarga berpendapatan rendah dan tinggi mayoritas tergolong tingkat asupan energi dan karbohidrat kurang. Berdasarkan hasil tersebut, dapat dikatakan bahwa tidak terdapat banyak perbedaan tingkat asupan antara balita pada keluarga berpendapatan tinggi dengan balita pada keluarga berpendapatan rendah. Hal ini didukung dengan hasil wawancara kepada ibu yang mengatakan bahwa balita baik dari keluarga pendapatan rendah maupun tinggi cenderung sedikit mengkonsumsi nasi yang merupakan sumber energi dan kandungan utama karbohidrat.

Penelitian sebelumnya bertentangan dengan hasil penelitian ini dengan mengatakan bahwa pendapatan dengan status gizi balita berdasarkan BB/TB memiliki hubungan bermakna. ${ }^{22}$ Penelitian lain yang dilakukan di Kabupaten Sragen juga mendukung pernyataan tersebut dengan menyatakan bahwa korelasi antara pendapatan dengan status gizi balita adalah berhubungan dan menghasilkan nilai $p=0,001 .{ }^{23}$ Perbedaan hasil penelitian ini dapat disebabkan adanya faktor lain selain pendapatan yang dapat menentukan status gizi balita, seperti faktor pendistribusian pendapatan yang digunakan untuk membeli bahan pangan dapat menentukan pemenuhan kebutuhan gizi dan berpengaruh terhadap status gizi balita. ${ }^{24}$ Penelitian ini meneliti pendapatan dan hubungannya dengan status 
gizi namun belum menganalisis variabel lain seperti pengeluaran terhadap pangan dan hubungannya dengan status gizi balita. Sehingga diperlukan penelitian lanjutan mengenai pengeluaran terhadap pangan dan non pangan dengan status gizi balita.

\section{KESIMPULAN}

Tingkat asupan energi dan karbohidrat dengan status gizi balita usia 2-5 tahun di Kecamatan Lenteng Kabupaten Sumenep memiliki hubungan yang bermakna. Semakin tercukupi tingkat asupan energi dan karbohidrat maka akan meningkatkan status gizi balita. Namun tidak ditemukan hubungan antara pendapatan keluarga dengan status gizi balita. Maka diperlukan penelitian lebih lanjut untuk menganalisis faktor lain yang dapat mempengaruhi status gizi balita serta hubungan diantara keduanya.

\section{ACKNOWLEDGEMENT}

Penulis berterima kasih kepada: Seluruh responden penelitian, Badan Kesatuan Bangsa dan Politik Kabupaten Sumenep, Dinas Kesehatan Kabupaten Sumenep, Puskesmas Lenteng Kabupaten Sumenep, Kantor Kecamatan Lenteng Kabupaten Sumenep yang telah memberikan ijin dan membantu berjalannya proses penelitian ini. dan seluruh dosen program studi Gizi Fakultas Kesehatan Masyarakat Universitas Airlangga beserta staf, terkhusus kepada dosen pembimbing sehingga dapat terselesaikannya penelitian ini.

\section{REFERENSI}

1. Fidiantoro, N. \& Setiadi, T. Model penentuan status gizi balita di puskesmas. Sarj. Tek. Inform. 1, 367-373 (2013).

2. Rochmawati, Marlenywati \& Waliyo, E. Gizi Kurus ( Wasting ) Pada Balita Di Wilayah Kerj Puskesmas Kota Pontianak. Vokasi Kesehat. II, 17 (2013).

3. Diniyyah, S. R. \& Nindya, T. S. Asupan Energi, Protein dan Lemak dengan Kejadian Gizi Kurang pada Balita Usia 24-59 Bulan di Desa Suci, Gresik. Amerta Nutr. 1, 341-350 (2017).

4. Lutviana, E. \& Budiono, I. Prevalensi dan Determinan Kejadian Gizi Kurang pada Balita. Kesehat. Masy. 5, 138-144 (2010).

5. Ni'mah, C. \& Muniroh, L. Hubungan Tingkat Pendidikan, Tingkat Pengetahuan Dan Pola Asuh Ibu Dengan Wasting Dan Stunting Pada Balita Keluarga Miskin. Media Gizi Indones. 10, 84-90 (2016).

6. Kurnia Illahi, R. Hubungan Pendapatan Kelarga, Berat Lahir, dan Panjang Lahir dengan Kejadian Stunting balita 24-59 bulan di Bangkalan. Manaj. Kesehat. Yayasan RS Dr. Soetomo 3, 1-14 (2017).

7. Kusumaningrum, F. \& Sudikno. Faktor-Faktor yang Berhubungan dengan Kegemukan pada Anak Balita 24-59 Bulan di Indonesia Tahun 2010. J. Gizi Indones. 35, 41-56 (2012).

8. Arifin, Z. Gambaran Pola Makan Anak Usia 3-5
Tahun Dengan Gizi Kurang Di Pondok Bersalin Tri Sakti Balong Tani Kecamatan Jabon -Sidoarjo. Midwiferia 1, 16-29 (2016).

9. Dewi, N. R. Faktor-Faktor Yang Mempengaruhi Status Gizi Pada Anak Balita Di Instalasi Rawat Jalan Rsud Ir. Soekarno Kabupaten Sukhoharjo. (Universitas Muhammadiyah Surakarta, 2018).

10. Rahim, F. K. Faktor Risiko Underweight Balita Umur 7-59 bulan. Kesehat. Masy. 9, 115-121 (2014).

11. Judistiani, T. D., Fauziah, A., Astuti, S., Yuliani, A. \& Sari, P. Gangguan Gizi Balita Di Desa Mekargalih Kecamatan Jatinangor - Sumedang: Masalah Kesehatan Masyarakat. J. Sist. Kesehat. 1, 84-91 (2017).

12. Erni, Juffrie, M. \& Rialihanto, M. P. Pola makan, asupan zat gizi, dan status gizi anak balita suku anak dalam di Nyogan Kabupaten Muaro Jambi Provinsi Jambi. J. gizi Klin. Indones. 5, 43 (2008).

13. Regar, E. \& Sekartini, R. Hubungan Kecukupan Asupan Energi dan Makronutrien dengan Status Gizi Anak Usia 5-7 Tahun di Kelurahan Kampung Melayu , Jakarta Timur Tahun 2012. JKI. 1, 184189 (2012).

14. Nagari, R. K. \& Nindya, T. S. Tingkat Kecukupan Energi, Protein Dan Status Ketahanan Pangan Rumah Tangga Berhubungan Dengan Status Gizi Anak Usia 6-8 Tahun. Amerta Nutr. 1, 189-197 (2017).

15. Virnanda, A., Pangestuti, Rahayuning, D. \& Rahfiludin, Zen, M. Hubungan Asupan makan (Karbohidrat, Protein, dan Lemak) dengan Status Gizi Bayi dan Balita (Studi pada Taman Penitipan Anak Lusendra Kota Semarang Tahun 2016). Kesehat. Masy. 4, 1-18 (2003).

16. Baculu, E. P. H. Hubungan Pengetahuan Ibu Dan Asupan Karbohidrat Dengan Status Gizi Pada Anak Balita di Desa Kalangkangan Kecamatan Galang Kabupaten Tolitoli. J. Kesehat. Masy. 7, 14 (2017).

17. Primashanti, D. A. D. \& Sidiartha, I. G. L. Perbandingan asupan energi, karbohidrat, protein dan lemak dengan angka kecukupan gizi pada anak obesitas. Medicina. 49, 173-178 (2018).

18. Kharismawati, R. \& Sunarto. Hubungan Tingkat Asupan Energi, Protein, Lemak, Karbohidrat, Dan Serat Dengan Status Obesitas Pada Siswa Sd. (Universitas Diponegoro Semarang, 2010).

19. Handayani, E. Pengaruh Pengetahuan Gizi Ibu Dan Pendapatan Orang Tua Terhadap Pola Makan Anak Balita Umur 6 Bulan - 5 Tahun Di Dusun 1 Desa Palumbungan Kecamatan Bobotsari Kabupaten Purbalingga. (Universitas Negeri Yogyakarta, 2014).

20. Wardani, G. A. P. Hubungan Karakteristik Ibu dan Pendapatan Keluarga Dengan Status Gizi Balita Di Wilayah Kerja Puskesmas Minggir Kabupaten Sleman Yogyakarta. (Universitas 'Aisyiyah Yogyakarta, 2016).

21. Wati, S. P. Hubungan Tingkat Pendidikan, Pengetahuan Ibu, dan Pendapatan Orangtua Dengan Status Gizi Anak Balita Usia 1-5 Tahun Di 
Desa Duwet Kecamatan Wonosari Kabupaten Klaten. (Universitas Muhammadiyah Surakarta, 2018).

22. Handini, D. Hubungan Tingkat Pendapatan Keluarga Dengan Status Gizi Balita di Wilayah kerja Puskesmas Kalijambe. (Universitas Muhammdiyah Surakarta, 2013).

23. Aryanti, M. A. Hubungan antara pendapatan Keluarga, Pengetahuan Gizi Ibu, dan Pola Makan dengan Status Gizi Balita di Wilayah Kerja Puskesmas Sidoharjo Kabupaten Sragen tahun
2010. (Universitas Negeri Semarang, 2010).

24. Susanti, I., Pambayun, R. \& Febry, F. Gambaran Faktor-Faktor Yang Mempengaruhi Status Gizi Anak Umur 2-5 Tahun Pada Keluarga Petani Di Desa Pelangki Kecamatan Muaradua Kebupaten Oku SelataN. J. Ilmu Kesehat. Masy. 3, 96-107 (2012).

25. Gibson, R.S. Principles Of Nutritional Assessment. (Oxford University Press, 2005). 